\title{
Irony According to Rorty's Human Philosophy Perspective
}

\author{
Martina Prativi'; Ahsan Siraj ${ }^{2}$ \\ ${ }^{1}$ Dance Study Program, Universal University, Batam, Indonesia \\ ${ }^{2}$ School of Management Engineering, Zhengzhou University, China \\ Corresponding Author: martina.prativi@uvers.ac.id
}

\begin{abstract}
In the humanist philosophy of Richard Rorty, the existence and concept of nihilism is used to scrutinize the theory of irony. Nihilism and the humanitarian crisis of cruelty underpin Rorty's philosophical thinking. One of his basic ideas is how humans have a particular attitude in perceiving reality, which can be found in terms of irony. This term provides a humanist grounding for coping with humanitarian issues in the present day, in this regard functioning as a frame for understanding put forward by Rorty within human selfhood. This literature review is based on both primary and secondary sources, with the formers referring to books written by Rorty, while the latter comprises information from books, journals, articles, and research papers discussing Rorty and human philosophy, especially existentialism. The research steps undertaken were data collection, classification, description, and analysis, and methodological elements were interpretation, heuristics, compilation, and reflection. The results provide an understanding of the use of Rorty's word, "irony," a consequence of humans tending to overlook their position as human beings. Humans are apparently ironic for seeing things critically, yet are capable of taking steps in any conditions. The meaning of irony can be understood as humans in the present day acting for others (in a social context). The virtue of ironists is conscious thought that may exist regarding the presence of others inside themselves, with language simply being an intermediary, functioning as a tool for dialectical needs. Humans construct history by considering three things that can be classified as morality, language, and socially constructed basic investigations.
\end{abstract}

Keywords: critical; dialectical; existence; human; irony; rorty

\section{INTRODUCTION}

It is no wonder that humans, as multidimensional, paradoxical, and dynamic creature, have multifarious outlooks. Current research is compelling on them ultifarious out looks of humans. This can be seen in the outlook of humans living in the ancient Greece period differing from those living during themedieval centuries, and both differin from out looks in the present day. Humans are historical creatures in which they cannot be detached from their cultural contexts; western and eastern people. These multifarious outlooks, grounded on the variety of human nature cannot be revealed as simply a single formulation of the problem. Humankind's special characteristic, among living creatures, is its multi-dimensionality. Humans themselves have both physical and spiritual characteristics as living creatures. They can think and reflect. Humans are living together by creating solidarity; it's most likely to find various dimensions at different ontological levels. Human truth, withitscomplexconstituents, haswhatcanbecalled anethical appeal (Snijders, 2004).

The formulation of a human -beingis paradoxical. This is commonly seen when humans reflect upon themselves. The definition of 'paradox' is different from 'contradiction'. Paradox contains two contradictions by which the truth of a paradox can be found within the units of both contradictory truths. By contrast, when one 
is considered to be true, the other one must be false, that is there is a contradiction. Paradox is concerned with humans' special characteristics in the world. Humans belong to nature as well as having a transcendental relationship toward it. Humans are free and bound, autonomous and independent, limited and unlimited, individual and social, pragmatic and impractical, physical and spiritual, transitory and eternal. Humans are those identified as paradoxical and dynamic living creatures, who live and move through their lives in the world. Humans move forward by constructing their own world Throughout this they reflect on? their relationships with their fellow human beings, they also havea uniqueness in those seeking to become closer to God. The term 'determinism' is a shared as pectof humankind being part of theworld of/ nature. The human dynamic is found within themselves. They are free and responsive, and also have a metaphysical dimension in them. In short, humans can be understood to be both free and ethically connected to others (Snijders, 2014).

This definition denotes that humans are given freedom and as such they can do anything they want in the world. The kinds of acts displayed by humans are to show off either their existence in the world (existence) or a devotion to God (religious). However, there are problematical cases a rising which cannot be denied in their relationships with other human beings. A serious issue, such as a dispute, cannot be simply be avoided since the main causal factor exists within harmonize society; this is known as 'dissimilarity'. A man is able to free others based on rational reasons, but also hurt others as a manifestation of freedom hencecommit acts of cruelty are an act concomitant with freedom. One's life is worthless when homicide is an alternative way to cope with problematical situations. The question then is how humans understand themselves as human beings in relation to God if they take another life.

The nature of existence and the concept of humanism are the bases used to examine Rorty's theory. Nihilism and the humanitarian crisis of cruelty cannot be neglected in any analysis of his thinking; they are core ideas found in Rorty's philosophical thought, re-asserting what is known as American pragmatism. Rorty's book entitled Contingency, Irony and Solidarity, returns to an ethical consideration, a belief that "cruelty is the worst deed." Rorty rejects any attempts to base his beliefs upon universal ethical principles Additionally, humans are not in trinsically inclined to cruelty but rather solidary. It is apparently not relevant as to whether such understanding is built upon a metaphysical base or general principles rather, what is required is to position Rorty's thought as a reflection of the present day.

Rorty's ideas are developed in his book entitled Contingency, Irony, and Solidarity. One of his analyses focuses on how humans behave in order to get close to reality. He idea he develops relies upon the concept of 'irony' which provides a human grounding in relation to his expectations of coping with current humanitarian issues. To understand the vast expanse of theworld, humans build social relationship with fellow human beings. One special characteristic is shown in humans facing reality. The word irony is employed to contradict certain things beyond one's life. This word indicates an event or is used to show a misfortune and heartbreaking incident. Irony describes unspoken explanations (something that goes 'out') both in oral and written language. Irony appears when a person reveals what is negative oras a criticism. However, sometimes it appears helpful for humans to consent, favor and help each other.

Irony is a word that is often used by humans in negating something from the side of their lives, an affirmation that is then negated. The word irony is often used to indicate satire or sad feelings. Irony itself is a term/ word that is included in the large Indonesian dictionary. The irony is used to provide an implicit explanation (of something 'out') in spoken or written language. The irony arises when humans express the negative side to criticize something. The irony is used to provide an implicit explanation (of something 'out') in spoken or written language. The irony arises when humans express the negative side to criticize something. Humans devote themselves to sharing with other human beings. Humans do things for other humans in helping, giving, giving up, and loving.

Rorty was deeply influenced by the thoughts of John Dewey and William James. What is true is not what best reflects reality, but by following James, "it is best for men if men believe in it." The philosophy is not to find the basis of everything that exists, but to become a means of self-development for the philosopher (Suseno, 2014). Rorty's contribution is philosophyist as a neo-pragmatist who enriches philosophy with his concept of irony.

\section{METHODOLOGY}

This qualitative research is based on data, which comprises primary sources (interpretandum) such as Contingency, Irony and Solidarity written by Richard Rorty and Jatidiri Manusia: Berdasar Filsafat Organisme Whitehead (Human self-identification) by Hardono Hadi including indirect supporting materials regarding the object of the research. 
This is historical research on philosopher. This qualitative research was conducted using descriptive philosophical method and philosophical analysis. The steps in this process were as follows: data collection, which included Rorty's works such as book, journals, and interviews; classificationof data, that selected data from chapters within the works in order to get a systematic understanding of key concepts; description, and data analysis

\section{RESULTS AND FINDINGS}

Richard Rorty was born on October 4, 1931 in New York City, America. He died at the age of 76 on June 8, 2007. Rorty grew up in a leftist family, meaning communism in keeping with the times. Rorty's political views were influenced by his grandfather who since an early age he had followed Trotsky's anti-Stalinist views. His family also adhered to the Jewish faith was just the same as the others. Trotsky's tenets constructed a belief system for his family although his parents never forced him from comply with they believed in. His father, James was a New York intellectual who did not explore philosophy in depth. James also became a member of the American labor party which was considered to be communist Following the1950s, Sidney Hook and James came to a decision to leave the party because of they had become anti-communist (1945-1956) and this is considered an unpopular manner. Since that day forth, Richard also became anti-communist influence his intellectual development (Knobe in Zulfis: 2002).

As a child, Rorty read a lot of the writings of Karl Marx inherited by his grandfather. With a family background that had known communist Rorty who brought Karl Marx to become an economist to become a great philosopher. Rorty's childhood life was occupied with reading the writings of Karl Marx. Marx's thoughts had an impact on Rorty's works. The influence of Karl Marx gave Rorty a radical mindset and this influence carried over to his personality. This is reflected in Rorty's works which are quite liberal, controversial, and deconstructive (Zulfis. 2002).

Rorty was a lecturer at Princeton University in 1961-1982 teaching Greek philosophy and analytic philosophy where his ideas began to draw attention and concurrently, enabled him to broaden his way of thinking. According to him, mastering analytic philosophy led to his appointment as a lecturer at Princeton University. The reason he studied analytic philosophy was not solely based on getting a position but rather he had to explore the types of analytic philosophy in order to examine potential transformative thoughts in twentieth century philosophy (Salatalohy, 2009). From 1982, Rorty taught philosophy at the University of Virginia and became a professor of humanity. In 1998, he had moved to Stanford University with the position of Comparative Literature Lecture and Philosophy Professor. He was also actively writing for a variety of journals. Throughout his career, he received many awards including: a Guggenheim Fellowship (1973-1974), Mac Arthur Fellowship (1981-1986). He was also given a prestigious lectureships at the College University (1986), the Clark Lectures at Trinity College, Cambridge (1987) and The Massey Lectures in Harvard (1997) (Stanford encyclopedia of Philosophy, 2001).

Consistent with his academic output, Rorty was viewed as both smart and radical. He had great intellectual capability as well as anextensive educational background in philosophy. In brief it can be said, he was becoming both a prominent philosopher and historian. He was a master in his field of philosophy and focusse do what he was passionate about producing many great works. His capability him to become an influential figure in America, particularly in developing the history of philosophy. He gave something new to the pragmatism school of philosophy. His work on neo-pragmatism brought back the spirit of pragmatism which is a prominent characteristic of American ideology. Rorty's intellectual courses are controversial as well as factual in a history of philosophy setting, and can be aligned with the work of other twentieth century philosophers such as Derrida, Foucault, Levinas, Althusser, Merleau-Ponty, Baudrillard, Duras, and Lyotard.

\section{Rorty's Theory of Irony}

Irony is a term used by Rorty which explainsh is conception of humans. Selfhood within humans is depicted in the notion of contingency. This conscious thought changes one's paradigm to irony. In his work Contingency, Irony and Solidarity, Rorty states that irony is the opposite of common sense. Irony is a term of selfunconsciousness to describe thefinal vocabulary on the whole, and so what is employed around is just considered as a habit. Common sense can be formula as a statement and found in thefinal vocabulary. The final vocabulary is deemed adequate to portray and assess beliefs, actions and lives of those with an alternative final vocabulary. For those things basically called common sense, humans tend to have self-confidence over themselves since it allows a certain kind of thought to develop. Once again, final vocabulary plays anessential part in analyzing irony.

The opposite of irony is common sense. To be make sense is to take for granted that statements formulated 
in that final vocabulary suffice to describe and judge the beliefs, actions and lives of those who employ alternative final vocabularies (Rorty, 1989). Irony is the main idea when the word she is used within the book, proposing a radical and skeptical view about reality. The use of the final vocabulary high lights the ironist's respond to certain language and its relation toward fellow human beings. An ironist is Rorty's expression for those who respond to other's final vocabularies in a particular way.

The Ironist is an insignificant and a history who thinks nothing has an intrinsic nature or a real essence. So, for an ironist the occurrence of a term like "just" or "scientific" or "rational" in the final vocabulary is no reason to think that Socratic inquiry into the essence of justice, science or rationality will take much beyond the language games of one's time. She spends time worrying about the possibility that she has been initiated into the wrong language game. She worries that the process of socialization which turned her into a human being by giving a language may have given the wrong language, and so turned her into the wrong kind of human being. But she cannot give a criterion of wrongness. So, the more she is driven to articulate her situation in philosophical terms, the more reminds herself of her footless by constantly using terms like "Weltanschauung, "perspective, "dialectic", "conceptual framework", "historical epoch", "language games", "re-description," "vocabulary" and "irony" (Rorty, 1989).

An ironist does not see the search for a final vocabulary (event in part) in such a way so as to get something distinct from the right vocabulary. They do not take the point of discursive thought to be to one of knowing that can be explained by the notion of reality, essence, objective point of view, and the corresponding reality of language. An ironist does not think thatthe point of philosophical enquir is to find an appropriate vocabulary to represent something transparently. They do not think of reflection as being ruled by those criteria, but rather their own points of view which are never more than platitudes in which they contextually determine the terms of the final vocabulary being used. As Rorty states:

By contrast, ironists do not see the search for a final vocabulary as (even in part) a way of getting something distinct from this vocabulary right. They do not take the point of discursive thought to know in any sense that can be explicated notions like "reality", "real essence", "objective point of view," and "the correspondence of language of reality". They do not think its point is to find a vocabulary which accurately represents something, a transparent medium. For the ironist, "final vocabulary" does not mean "the one which puts all doubts to rest" or "the one which satisfies our criteria of ultimate, or adequacy, or optimality." They do not think of reflection as being governed by criteria. Criteria, on their view, are never more than the platitudes which contextually define the terms of a final vocabulary currently in use (Rorty, 1989).

An ironist is a nominalist and historicist. A nominalist can be defined as someone who thinks there is nothing which has an intrinsic nature and a real essence. Therefore, Socrates 'notion of essence, in term of justice, science or rationality, is simply a language game, an allurement to think about the reasons used as a basis to look for knowledge or rationality and justice. For the ironists, this is just simply a final vocabulary and thought in every possibility within the wrong language game. The concern of the ironist is that with the process of socialization it may change her into a human being who playing the wrong language game. However, this mistake cannot provide the wrong criteria. Hence a nominalist may find out the philosophical meaning in any situation employing the terms of final vocabulary or irony. A nominalist does not accept that there is a reality in nature but an ironist does apply another. Final vocabulary is a tool used as long as it can be used. If it is no longer used in a particular environmental setting, an ironist makes a replacement with a new vocabulary, whether it is created by her or by others.

An ironist can be said to be a total skeptic since she rejects the concept of an essence that reality is out there and believes in self-truth. This is in contrast to the metaphysician who inquires into the truth out there, to find an essence. By putting doubt over a reality, it does not mean rejection of all the things relying upon it. This behavior fundamentally remains fanatic and tendentious that may be considered excessive in certain things. An ironist realizes that final vocabulary is not actually the final vocabulary. A final vocabulary, as long as it can be used and it is still relevant, will be constant. This idea belongs to a school in the philosophical field known as Pragmatism which is concerned with logical thought in all matters as being the most important act. This school which was born in America had helped Rorty in understanding his own contingency to cope with language. In his book Consequences of Pragmatism, he clarifies his criticism towards essentialism, by which, of course it is the thinking of an ironist. Thus, it can be said:

My first characterization of pragmatism is that it is simply anti-essentialism applied to notions like "truth", "knowledge", "language", "morality", and similar objects of philosophy theorizing. Let me illustrate this by James's definition of "the true" as "what is good in the way of 
belief." This has struck his critics as not to the point, as unphilosophical. As like the suggestion that essence of aspirin is that it is good for headaches. James's point, however, was that there is nothing deeper to be said: truth is not the sort of thing which has an essence. More specifically, his point was that it is no use being told that truth is "correspondence to reality". Given a language and a view of what the world is like, one can, to be sure, pair off bits of the language with bits of what takes the world to be in such a way that the essence one believes true have internal structures isomorphic to relation between things in the world. When we shout up routine under liberated reports like "this is water", "that's red", "that's immoral", our short categorical sentences can easily be thought of as pictures, or as symbols which fit together to make a map. Such reports do indeed pair little bits of language with little bits of the world. Once one gets to negative universal hypothetical and the like, such pairing will become messy and ad hoc, but perhaps it can be done. James's point was that carrying out this exercise will not enlighten us about why truths are good to believe, or offer any clues as to why or whether our present view of the world is, roughly, the one we should hold. Yet nobody would have asked for a "theory" of truth if they had not wanted answers to these latter questions. Those who want truth to have an essence want knowledge, or rationality, or inquiry, or the relation between thought and its object, to have an essence. Further, they want to be able to use their knowledge of such essence to criticize views they take to be false and to point the direction of progress toward the discovery of more truths. James thinks these hopes are vain. There is no essence anywhere in the area. There is no wholesale, epistemological way to direct or criticize, or underwrite, the course of inquiry (Rorty, 1982).

This statement describes a skeptic but it does not mean that she has no firm beliefs but rather a critical position in all matters that is, it's about not taking anything for granted. A radical ironist admits the vocabulary she has employed can be easily criticized by other individuals. Skeptical is one method to present an ironist to be dialectical need. The word dialectical for the ironist refers to the use of vocabulary rather than formulating a proposition. The vocabularies are used to re-describe a conclusion. Consequently, brand new vocabularies develop as a response of ironist creativity. The awareness of contingency on final vocabulary is precisely impacted for those ironists to pursue criticism. A frequently asked questions regarding the concepts of an ironist is that if an ironist avoids using the final vocabulary, would she be totally sceptic and cannot settle upon certain beliefs ? Does not an ironist have to be the one without any beliefs? Rorty rejects this sort of conclusion. Realizing views may change from time to time, it does not mean they can be disregarded. Humans who are ironic over convictions still can be seen to have firm beliefs, or even having willingness to die while final vocabularies have not changed (Suseno, 2004).

Rorty's position is radically ethnocentric. The thought is determined by the language that has been learned and each language embodies a distinctive culture, with world views, beliefs, values, and ideals of its own. But language is contingent, meaning that the language culture into which something coincidental is born. For example, whether someone is born as Javanese or Hulu or German or Japanese is a coincidence, even though everyone has a language with their own views. From this contingency Rorty draws the conclusion that world views, beliefs, and beliefs are accidental in nature. Therefore, what should be asked, according to Rorty, is not which beliefs and beliefs are true, but which ones are more helpful to develop (Suseno, 2000).

The man of irony doesn't see the final vocabulary as a way of getting something different from the correct vocabulary. They (the men of irony) do not take a discursive thought in order to know. Thought that can explain a reality, essence, objective point of view, and correspondence, but reflective thinking with its own point of view. This kind of thinking is more towards thinking from a subjective point of view. An ironic does not think at the point of how to find the right vocabulary to represent something that is transparent or closed, but a final vocabulary is a place of doubt that is used to not meet the criteria of absolutes. They (ironic humans) think reflection without being regulated by contextual criteria to define the final vocabulary that is being used today. The human irony is a total skeptic, but that does not mean he is not critical of everything.

Rorty on logic by showing that language is outside of humans. It does not denote that the language itself as reality. Language, according to him, is a tool without any truth. A tool used to express what humans are thinking about as it is humans which create language propositions which are taken from pre-existing vocabularies. There is an attempt to find out the truth outside humans as an objective truth. Metaphysical Vocabularies is assumed have a go of universal vocabularies. This is different to Rorty's explanation of ironists who sees the truth as not in final vocabularies, that the truth extends an essence of righteous manifestation. Thus, an ironist for a metaphysician may be called relativistic.

The metaphysician responds to that sort of talk by calling it "relativistic" and insisting that what matters 
is not what language is being used but what is true. Metaphysicians think that human beings by nature desire to know. They think this because the vocabulary they have inherited, their common sense, provides them with a picture of knowledge as a relation between human beings and "reality", and the idea that we have a need and a duty to enter into this relation. It also tells us that "reality", "if properly asked, will help us determine what our final vocabulary should be. So, metaphysicians believe that there are, out there in the world, real essence which it is our duty to discover and which disposed to assist in their own discovery. They do not believe that anything can be made to look good or bad being redescribed - or, if they do, they deplore this fact and cling to the idea that reality will help us resist such seductions (Rorty, 1989).

Rorty's idea that the "Truth cannot be out there"contains the proposition that there are no sentences of truth out there in which the truth can lay on propositions formulated by human beings. A series of sentences that consists of a variety of words is an element of language where the language itself is produced by human creativity. Truth cannot be out there - cannot exist independent of the human mind-because sentences cannot exist, or be out there. The world is out there, but descriptions of the world are not. Only description of the world can be true or false. The world on its own-unaided by the describing activities of human beings - cannot (Rorty, 1989).

Truth does not reside out there because sentences containing truth cannot exist by themselves. Truth cannot be free asit deals with human beings. While it is true that the world is out there, but descriptions of the world are not out there. Rorty views the description of the world can be either right or wrong while the world on its own cannot be determined the same way.

\section{Ironists on Human Philosophy Perspective}

Discussing human historicity is the same as exploring human experiences. Understanding history is easy to understand humans. Humans are historical agents. An ironic by Rorty describes the human condition of existence. An irony human is presence in the world as a concrete thing consists of body and soul. As real human beings, irony humans are in the form of material who have a soul to fill the world. The human presence is a form of learning from human experience in creating history.

When discussing human beings, it is just the same as revealing human experiences. In this regard, understanding certain aspects of history canaid in getting to know human beings. Humans are an historical agent. An ironist, according to Rorty, describes human existence, in which, the ironist's existence is something concrete, formed of body and soul. As a real human, the ironist has a soul to complete the world. Human existence is a learning medium of human experiences inthe making of history. Ordinary experience is simply the common one, emphasizing that humans are living creatures that breathe, amend, and adapt and these naturally go on. To start life, humans are born into the world apoint marking the beginning of a human's existence. Having instincts to walk around, move, consume food, drink, and find a proper house are human characteristics in nature. These behaviors are daily activities without any significant meaning. Without any kind of process, ordinary human beings are still able to carry out their daily activities at all times. This immediate experience is interpreted slightly different for the ironists.

Ironists define the meaning of immediate experience as simply 'ordinariness', something which is continually taking place without any innovation or creativity. It is spontaneous as people uttering words while they speak. Sound produced in talking is something which is being thought of in the form of language. This behavior generally impacts on human actions. These actions are natural without any mean behind all. There is no distinction in a general way when humans display their behaviors toone another. An immediate experience is categorized as something readily known and repeated in society, likewise animals and plants, constant and monotonous. So they are unchanged at all. Spontaneously speaking is a matter of irony by which spontaneity does not require any reasons behind this activity. It comes up and out like breathing and habitual things beside eating, drinking, and move in a natural activity setting. Instinctive acts, regardless of rationale, human actions which can be considered as irony. Human action is the instinctive act of someone acting without the following reason, actions that use sensitive conscience and feelings.

\section{Pre-philosophical Experience of Irony}

Pre- philosophical experience denote human experiences at the beginning of mentioning things, words, and speaking Human experience makes an acquaintance with the human world that already exists in terms of culture and language. Humans acknowledge and understand culture as it is a compulsory aspect of life for human beings. Human experience further leads to social activity and interaction with other humans or the feelings themselves which most likely starts to grow up. In brief, those feelings are enclosed in language, as with a kind of human existence as subject. Communication is an important process to maintain one's relationship with fellow human beings. Language provides the medium for 
subject to subject or subject to object communications The connections established present human culture attribute to an environmental setting. where humans grow within it or adapt. Pre-philosophical experiences are those presenting the selfhood into the world, having particular feelings, and being subjects.

These are the most likely experience which ironists are expecting. Subjective experience extends to any kind of form and situation, continuously changes. Being ironist means they have their own places to exercise freedom of expression and creativity. This is where humans are engaged with language, but language is merely a tool, according to ironists. Regarding language, the world is indeed found outside of humans, and language itselfisa part of the world. Language has nothing to do with the truth of reality out there, it is simply a tool for communicating and interacting among human beings and this, according to Rorty, is repeated words that have found and accepted previously.

Language allows representation of human thoughts outside themselves. It is possible for a new vocabulary to develop. There are many possibilities as to how new vocabularies can be introduced within human thought Ironists particularly possess the capability in establishing entirely new vocabularies. In Contingency, Irony, and Solidarity, metaphysical language is always searching for the unshakeable main core (main language) while ironists rely on logic, as Rorty said. The searching of the ideal language differs from the logical language which by contrast the logic of language. The main core of metaphysical language is to find original truth, while the logic of language tends to find out the meaning of language. Whether the logic of language is meaningful or meaningless, it is essential as it plays a role as language introduces propositions. In regard to ironists, they use language as a dialectical method. Despite rejecting final conclusions, ironists understand any sort of vocabularies as propositions of repeated words, hence ironists are considered relativistic, and it is closely related to semantics and pragmatics. That language understanding is pioneer of further metaphor in language.

\section{Human Philosophical Experience on Irony}

Basic experience is full of experience and dominated by common sense. Basic experience includes three age dimensions, that is past, present and future. Dimensions help humans to contemplate the world. The very basic difference among animals and humans is that humans are blessed with 'wisdom' from the time when they came into existence. Reflection is the act of giving certain values to history for identification of themselves. The identity is a part of human personalities, in which self-identification is the most important part of it. It gives directions to one's goals. As human are responsible for their futures and for this purpose they give value to their future. Humans cannot get rid of their past, which is to act regardless of their previous mistakes. However, past, present and future times are human dimensions in which they ruminate over their basic experience.

As for explanation mentioned previously about how ironists attempt to deal with three dimensions in past, present, and future time. In line with Rorty's Contingency, Irony, and Solidarity, the notion of 'being explained' is the opposite to 'making sense'. Ironists cannot focus attention over their own world reflection. This places the human behavior based on something illogical. The acts are without any rumination and are practical and beneficial for human beings. The acts are learnt from past experiences which can be carried on in the present day and are novelties in the forthcoming. Ironists do not imply the meaning of life emerges by reflecting at length on past romanticism, but rather see an individual who present themselves in the present day as conforming between ideas and reality. This pragmatic act shows fundamental experience committed by ironists as a form of existential reflection. Human existence in the world provides significant in them to find the meaning of life. Human beings are basically capable to live life just the way seen fit performing useful acts and establishing their own history. So, this practice is considered to be something worthwhile.

The weakness of Rorty's thought is that ironists exist without being able to cope with issues as they are set on doubting. This can be seen clearly when a conflict or singular issue emerges in a person's life. Ironists are not able to comport themselves in a conflict, in fact the problem will then be more crucial if they serve in a role as peace-makers. Therefore, ironists cannot play a role in the midst of crucial issues for instance conflict, controversy, war, tragedy, turmoil, a natural disasters and ethical dilemmas. Ironists are just the same as those who are behind the scenes and emerge when the events have taken place. Ironists' presence is as anticipatory agents in face of such conflicts. They provide solutions and comments; however, they do not play a direct part in the matter. For instance, a man is watching a show from his seat, the act is being observed and it exists. Then, a volunteer that comes after a tragedy has happened, he prepares for action practically. The superiority of Rorty's thought regarding irony is that humans realize things for themselves as complete human beings. The human characteristics seem very strong and real, neither utopian nor humane. As 
noted by Raharjo, the term utopia is derived from Greek, derived from out that means no, or simply escapism topos that means place, so utopia means "imaginary land", a place in a pipe dream, for example, dreaming of an ideal state, or commonwealth that is divorced from considerations of human imperfections (Rahardjo, 1992: 18). Rorty expresses the idea that humans are the source of all things and the reason why relationships among fellow humans becomes close, they create peace and harmony in neighborhoods without committing wrong doing by forgetting about culture, local language, and customs. They become more responsive to their surroundings. Furthermore, humans think independently, critically, creatively and become content in the future.

\section{CONCLUSION}

It can be concluded that Rorty's thought, based on the ontology of human beings, confirms that humans have a close relationship with each other. A pragmatic relationship is apparently having the same purpose, that is living as fellow human beings in the world. Humans are the subject, as well as the object. According to the manifestation of existence, humans are intensively engaged without hers. Ironists consider themselves to be an irony as human beings. They realize the others presence in the world; hence they act toward others and their surroundings. Rorty's thought may seem subjective and to fail to offer tools for problem solving. Rorty's thought tends to set out certain attitudes toward oneself that seem ironic. Ironists differ from the common human beings who possessive strong and strict faiths. To be an ironist denotes that one has certain beliefs as an individual, and recognizes others' beliefs. Ironists accentuate individual acts rather than absolute thought, so its preference simply refers to meaningless experience.

In epistemology, Rorty's word, irony, is defined as a term used to provide an explanation about human beings. For ironists, there is a disconnect between thought and reality, and they argue that language is used simply as a tool, as opposed to a medium to describe reality. They truly understand what contingency in reality is. Ironists believe the existence of reality in the real world is out there and that it is not found within language. They are free to criticize yet are always prepared to be criticized. Ironists play a part in such radical ways. It is evident in the history of philosophy that Rorty's thought tends to be realistic, as he denies the entity of reality. It seems to be dynamic and continuous in order to find the truth. Hesitancy may cause the ironists to become sensitive and unsure of certain things, including themselves. This occurs for the ironists who know that truth is changeable in different conditions. These conditions allow such prephilosophical experience in constructing a brand-new experience.

The ironic significance of human beings builds a pragmatic existential relationship. The positive point of being an ironist is being open to opportunities, thinking radically, and maturing one's thinking before an act is going to be committed. The negative aspect is that ironists build practice relationships without any bonds, a relationship that has a purpose and a future with all of the possibilities that occur-like a mutually beneficial relationship with each other. An ironist prioritizes thinking of the present as a valuable experience that cannot be overlooked. In human essence, Rorty's thoughts seem original and unique. Dialectics is the key and creates harmony in society. Humans who take advantage of other people at the same time provide benefits to others with useful action. Humans together create something in the form of new ideas logically and continue to respect each other without hurting each other. Experiences such as these are fundamental because they create actions that relate to the past and the future by reflecting on the present.

For ironists, it is necessary to think about the present day as a valuable experience. The essence of Rorty's thought is arguably original and unique. The dialectical method is the main base on which harmony is built in a diverse society. Ironists do not take things for granted when obtaining something from others, instead performing acts in return that are useful to others. They are humans simultaneously creating logical ideas and appreciating other fellow beings without being offensive by any possible means. This is a kind of fundamental experience since it constructs some acts closely related to the past and future, by reflecting beforehand what it is in the present day.

\section{REFERENCES}

Abidin, Zaenal (2009). Filsafat Manusia: Memahami Manusia Melalui Filsafat. Bandung: PT Remaja Rosdakarya.

Anastasia, Jessica A.S. (2015). Menelusuri Pragmatisme: Pengantar Pada Pemikiran Pragmatisme dari Peirce hingga Habermas. Yogyakarta: Kanisius.

Armin, Adi (2003). Richard Rorty (Pendiri Pragmatisme Kontemporer). Yogyakarta: TERAJU.

Bagus, Lorens (2005). Kamus Filsafat. Jakarta: PT Gramedia Pustaka Utama.

Bakker, Anton dan Zubeir, Achmad Charis (1992). 
Metodologi Penelitian Filsafat. Yogyakarta: Penerbit Kanisius.

Bakker, Anton (2006). Antropologi Metafisik. Yogyakarta: Penerbit Kanisius.

Brandom, Robert B. (2000). Rorty and His Critics. Massachussetts USA: Blackwell Publisher Inc.

Fahmi Salatalohy (2009). Kontingensi Bahasa Dalam Pandangan Neopragmatisme Richard Rorty (19312007). Unpublished Dissertation.

Hadi, Hardono (2000). Jatidiri Manusia: Berdasar Filsafat Organisme Whitehead. Yogyakarta: Penerbit Kanisius.

Hadi, Hardono (2014). Potret Siapakah Aku? Yogyakarta: Penerbit Kanisius.

Hardiman, Budi (2015). Seni Memahami: Hermeneutik dari Scheiermacher sampai Derrida. Yogyakarta: Kanisius.

Hadi, Hardono (2003). Heidegger dan Mistik Keseharian Suatu Pengantar Menuju Sein dan Zeit. Jakarta: KPG (Kepusatakaan Populer Gramedia).

Hadi, Hardono (2011). Pemikiran-pemikiran yang membentuk Dunia Modern (Dari Machiavelli sampai Nietzsche). Jakarta: Penerbit Erlangga

Irawan (2008). Animal Ambiguitas. Yogyakarta: Jalasutra.

Kaelan (2009). Filsafat Bahasa Semiotika dan Hermeneutika. Yogyakarta: Paradigma UGM.

Keraf, A. Sony (1987). Pragmatisme Menurut William James. Yogyakarta: Kanisius.

Louis, Leahy (2001). Siapakah Manusia? Yogyakarta: Kanisius.
Mustansyir, Rizal (2007). Filsafat Analitik: Sejarah, Perkembangan dan Peranan Para Tokohnya. Yogyakarta: Pustaka Pelajar.

Niznik, Josef; Gellner, Ernest (2002). Memperdebatkan Status Filsafat Kontemporer: Habermas, Rorty, dan Kolakowsky. Yogyakarta: Qalam.

Pepperell, Robert (2009). Posthuman: Kompleksitas Kesadaran, Manusia dan Teknologi. Yogyakarta: Kreasi Wacana.

Prasetyono, Emanuel (2013). Dunia manusia, manusia mendunia: buku ajar Filsafat Manusia. Sidoarjo: Zifatama Publishing.

Rahardjo (1992). Pragmatis Medan Utopia: Corak Nasionalisme Ekonomi Indonesia. Jakarta: LP3ES.

Rorty, Richard (1980). Philosophy and the mirror of nature. Oxford: Basil Blackwell.

Rorty, Richard (1982). Consequences of pragmatism. Minenepolis: University of Minnesota Press.

Rorty, Richard (1989). Contingency, Irony and Solidarity. Cambridge: Cambrige University Press.

Snijders, Adelbert (2014). Antropologi Manusia: Manusia Paradoks dan Seruan. Yogyakarta: Penerbit Kanisius.

Sugiharto, I Bambang (1996). Postmodernisme. Yogyakarta: Kanisius.

Sunardi, St. (1996). Nietzsche. Yogyakarta: LkiS.

Suseno, Franz-Magnis (2000). 12 Tokoh Etika Abad ke-20. Yogyakarta: Kanisius.

Wahana, Paulus (2004). Nilai Etika Axiologi Max Scheler. Yogyakarta: Kanisius.

Zulfis (2002). Kritik Richard rorty terhadap fondalisme (sebuah tinjauan epistemology). Unpublished Thesis. 